\title{
Parent and friend influences on the multiple health behavior of Pacific Islander adolescents
}

\author{
Karly S. Geller ${ }^{1 *}$, Taylor A. Hendricks ${ }^{1}$, Antonia R. Alvarez ${ }^{2}$, \\ Keean C. A. Braceros ${ }^{2}$, Claudio R. Nigg ${ }^{3}$ \\ ${ }^{1}$ Department of Kinesiology \& Health, Miami University, Oxford, USA; \\ *Corresponding Author: gellerks@miamioh.edu \\ ${ }^{2}$ Prevention and Control, University of Hawaii Cancer Center, Honolulu, USA \\ ${ }^{3}$ Department of Public Health Sciences and Epidemiology, University of Hawaii at Manoa, Honolulu, USA
}

Received 18 August 2013; revised 18 September 2013; accepted 11 October 2013

Copyright (C) 2013 Karly S. Geller et al. This is an open access article distributed under the Creative Commons Attribution License, which permits unrestricted use, distribution, and reproduction in any medium, provided the original work is properly cited.

\begin{abstract}
Youth obesity has increased dramatically in the United States, disproportionally affecting Hawaiian populations. The primary research objective was to describe the influence of parent and friends on the dietary, physical activity, and sedentary behaviors of Pacific Islander high school students. Data were collected from classrooms within a private high school on the Hawaiian island Oahu. Participants were Pacific Islander adolescents attending a high school in Hawaii. Participating adolescents completed a questionnaire, followed by a corresponding focus group; specifically reporting the social-level influences on their dietary and activity behaviors. Adolescents then interviewed their parent/guardian, asking questions relative to their perceived health-related influence. Participating adolescents $(N=60)$ were $53 \%$ female with a mean age of 16.93 (SD = 0.63), and their parents/guardians $(N=47)$ were $75 \%$ female with a mean age of 46.72 (SD = 5.11). Outcomes revealed parents $/$ guardians as the dominant influence on adolescents' dietary behaviors, and time spent with parents was almost exclusively sedentary. In comparison, adolescents were more active with friends, but shared less healthy dietary habits. Results provide groundwork for similar examinations and culturally tailored interventions among similar adolescent populations.
\end{abstract}

Keywords: Pacific Islander; Obesity; Adolescents; Nutrition; Physical Activity

\section{INTRODUCTION}

The United States (US) has experienced a drastic increase in obesity among adolescent youth, becoming an epidemic and public health concern. Population-level surveillance has revealed a $5 \%$ to $18 \%$ increase in obesity among adolescents (12 to 19 years old) [1], and obese youth commonly become obese adults [2]. The continuous rise in obesity prevalence is concerning given strong association with numerous adverse medical $[3,4]$, psychosocial [5], and economic consequences [6]. Compared to other ethnic groups, the rates of obesity and related illnesses are disproportionally higher among Hawaiian youth [7-9].

Obesity is a consequence of excessive energy intake and/or insufficient energy expenditure (i.e., energy imbalance), which is largely influenced by activity and dietary patterns. Previous research has revealed strong relationships between energy imbalance and specific modifiable behaviors, including physical activity (PA) [10], excessive screen time [11], and dietary patterns [12]. Unfortunately, only $8 \%$ of American adolescents (majority White European American) perform enough PA to experience the health benefit [13], and the risk of inactivity is greater among Pacific Islander youth [14,15]. Relative to sedentary behavior, school-aged youth are recommended to spend no more than 2 hours a day in front of the television and/or computer (i.e., screen time) [16]; however, $32 \%$ and $31 \%$ of youth reported watching television for three or more hours on a regular school day and using the computer for 3 or more hours, respectively [17]. Among American youth, television time is negatively associated with fruit and vegetable intake [18], facilitating over-consumption of calorie-dense foods [19]. 
The rates of excessive television viewing are similar among Native Hawaiian and Pacific Islander populations [20], and Hawaiians typically report high fat intake and low fruit and vegetable consumption [15].

The social ecological model is a holistic framework to determine the multilevel influences on health and health behavior. The framework examines individual level influences (e.g., self-efficacy, knowledge, etc.), as well as factors within one's social (e.g., shared time, social support, etc.) and physical environments (e.g., accessibility to supportive school resources, community resources, etc.) [21]. The current research targeted adolescents' multiple health behavior within the social environment, examining the influence of parents and friends. Parents significantly impact their child's risk of obesity via considerable influence on family eating patterns [19], activity levels, and sedentary behavior [22-24]. However, autonomy increases during adolescent development, heightening the influence of peer/friend interactions on adolescents' health behaviors [25-27]. Evidence to clarify distinctions between the parent and friend influence is limited [28], and parallel examinations among Pacific Islander adolescents are deficient.

The current study gathered quantitative and qualitative data from Pacific Islander adolescents and their parents/ guardians. The presence of two sources of social support (parent and friends) was examined relative to Pacific Islander adolescents' multiple health behavior; specifically describing the influence of shared time, perceived influence, and the general social environment. Strong evidence suggests high cultural awareness among ethnic minorities, which impact their habitual behavior [29]. Appropriately tailored obesity prevention programs have successfully improved dietary habits, physical activity levels, and sedentary time among ethnically diverse youth [30]. However, such success requires specific, preliminary examinations to inform effective intervention development. The primary study objective was to generate preliminary understanding of the social-level influences on Pacific Islander adolescents' multiple health behavior. In absence of direct-comparative research, many priori hypotheses were made and analyses were exploratory and descriptive.

\section{METHODOLOGY}

Informed consent preceded all study procedures, which were approved by the University Institutional Review Board and the State of Hawaii Department of Education. Participating adolescents $(N=60)$ were 10th-12th grade students recruited from two classrooms at a private high school in Hawaii. Participating students elicited the participation of one parent/guardian $(N=47)$. The private school includes kindergarten-12th grade students $(N$ $\approx 3,200$ ). Only $50 \%$ of tuition costs are paid by students' families; and, at the time of the study, $45 \%$ of enrolled students received financial aid to cover remaining costs. The participating classrooms were specifically targeted for the school's admission policy, which gives strong preference to applicants of Native Hawaiian ancestry. All participating adolescents and parents/guardians were of Native Hawaiian ancestry.

Adolescent surveys asked students to report the number of daily meals, physical activities, and sedentary activities shared with their parents and friends. Questions also targeted participating adolescents' perceived parent/ friend social support for these health behaviors and any previous behavior changes via open-ended questions. Adolescent-led interviews gathered qualitative information on their parent/guardian's typical health behavior (diet, physical activities, and sedentary activities), perception of adolescent health behaviors, and perceived influence on adolescent health behavior (diet and usual activity).

Quantitative data analysis was descriptive, including mean and proportion calculations. The average daily meals, weekly physical activities, and daily sedentary hours shared between adolescents and their parent/ guardian and friends were averaged and reported as means (M) and standard deviations (SD). Qualitative data were conceptualized into underlying themes based on the targeted health behavior and the source of social support. Given the guiding nature of survey questions, a content analysis approach was sufficient in systematically analyzing the content and frequency of participants' qualitative responses. Specifically, all participant responses were color-coded based on broader concepts to develop a response key. Guided by the response key, similar responses were grouped and rank-ordered by frequency. Finally, grouped responses were interpreted by a panel of experts relative to previous evidence regarding the underlying influences on the obesity-related behaviors of youth. The expert panel included the current researchers and focus group moderator, a Pacific Islander research assistant, and two ethnically diverse adolescent research assistants, living in Hawaii. Coding and grouping was approved by each panel member before being finalized

\section{RESULTS}

Table 1 describes all adolescent and parent/guardian demographic data and health-related shared time by participant gender and source of social support. On average, shared meals with adolescents were similar between parents/guardians and friends. Both male and female adolescents shared considerably more weekly physical activity with their friends versus their parent/guardian; specifically, females and males shared approximately 3 and 4 times more physical activity with friends, respectively. 
Table 1. Participant demographics and adolescent self-reported shared time.

\begin{tabular}{|c|c|c|c|c|}
\hline \multirow{2}{*}{$\begin{array}{c}\text { Sample } \\
\text { Demographics }\end{array}$} & \multicolumn{2}{|c|}{ Adolescents } & \multicolumn{2}{|c|}{ Parents } \\
\hline & Male & Female & Fathers & Mothers \\
\hline $\mathrm{N}(\%)$ & $\begin{array}{c}28 \\
(47.5 \%)\end{array}$ & $\begin{array}{c}31 \\
(52.5 \%)\end{array}$ & $\begin{array}{c}12 \\
(25.5 \%)\end{array}$ & $\begin{array}{c}35 \\
(74.5 \%)\end{array}$ \\
\hline M Age (SD) & $\begin{array}{l}17.08 \\
(0.620)\end{array}$ & $\begin{array}{l}16.80 \\
(0.619)\end{array}$ & $\begin{array}{l}47.78 \\
(5.129)\end{array}$ & $\begin{array}{c}46.37 \\
(5.148)\end{array}$ \\
\hline Ethnicity & N (\%) & $\mathrm{N}(\%)$ & N (\%) & N (\%) \\
\hline Asian/White & $\begin{array}{c}7 \\
(25 \%)\end{array}$ & $\begin{array}{c}10 \\
(31.3 \%)\end{array}$ & $\begin{array}{c}2 \\
(15.4 \%)\end{array}$ & $\begin{array}{c}6 \\
(17.1 \%)\end{array}$ \\
\hline African American & $\begin{array}{c}0 \\
0 \%\end{array}$ & $\begin{array}{c}1 \\
3.1 \%\end{array}$ & $\begin{array}{c}0 \\
0 \%\end{array}$ & $\begin{array}{c}0 \\
0 \%\end{array}$ \\
\hline Asian & $\begin{array}{c}10 \\
35.7 \%\end{array}$ & $\begin{array}{c}9 \\
28.1 \%\end{array}$ & $\begin{array}{c}8 \\
61.5 \%\end{array}$ & $\begin{array}{c}17 \\
48.6 \%\end{array}$ \\
\hline Native Hawaiian & $\begin{array}{c}5 \\
17.9 \%\end{array}$ & $\begin{array}{c}3 \\
9.4 \%\end{array}$ & $\begin{array}{c}0 \\
0 \%\end{array}$ & $\begin{array}{c}4 \\
11.4 \%\end{array}$ \\
\hline $\begin{array}{c}\text { Hispanic/ } \\
\text { Latino/Asian/White }\end{array}$ & $\begin{array}{c}1 \\
3.6 \%\end{array}$ & $\begin{array}{c}2 \\
6.3 \%\end{array}$ & $\begin{array}{c}0 \\
0 \%\end{array}$ & $\begin{array}{c}1 \\
2.9 \%\end{array}$ \\
\hline African American /White & $\begin{array}{c}1 \\
3.6 \%\end{array}$ & $\begin{array}{c}0 \\
0 \%\end{array}$ & $\begin{array}{c}0 \\
0 \%\end{array}$ & $\begin{array}{c}0 \\
0 \%\end{array}$ \\
\hline Asian/Portuguese & $\begin{array}{c}0 \\
0 \%\end{array}$ & $\begin{array}{c}1 \\
3.1 \%\end{array}$ & $\begin{array}{c}0 \\
0 \%\end{array}$ & $\begin{array}{c}1 \\
2.9 \%\end{array}$ \\
\hline White & $\begin{array}{c}2 \\
7.1 \%\end{array}$ & $\begin{array}{c}2 \\
6.3 \%\end{array}$ & $\begin{array}{c}2 \\
15.4 \%\end{array}$ & $\begin{array}{c}3 \\
8.6 \%\end{array}$ \\
\hline $\begin{array}{c}\text { Hispanic/ } \\
\text { Latino/White }\end{array}$ & $\begin{array}{c}0 \\
0 \%\end{array}$ & $\begin{array}{c}2 \\
6.3 \%\end{array}$ & $\begin{array}{c}0 \\
0 \%\end{array}$ & $\begin{array}{c}1 \\
2.9 \%\end{array}$ \\
\hline $\begin{array}{c}\text { Hispanic/ } \\
\text { Latino/Asian }\end{array}$ & $\begin{array}{c}0 \\
0 \%\end{array}$ & $\begin{array}{c}0 \\
0 \%\end{array}$ & $\begin{array}{c}0 \\
0 \%\end{array}$ & $\begin{array}{c}1 \\
2.9 \%\end{array}$ \\
\hline $\begin{array}{c}\text { Hispanic/Latino/Portuguese/ } \\
\text { White }\end{array}$ & $\begin{array}{c}0 \\
0 \%\end{array}$ & $\begin{array}{c}0 \\
0 \%\end{array}$ & $\begin{array}{c}0 \\
0 \%\end{array}$ & $\begin{array}{c}1 \\
2.9 \%\end{array}$ \\
\hline $\begin{array}{l}\text { Portuguese/Asian/ } \\
\text { White }\end{array}$ & $\begin{array}{c}1 \\
3.6 \%\end{array}$ & $\begin{array}{c}0 \\
0 \%\end{array}$ & $\begin{array}{c}0 \\
0 \%\end{array}$ & $\begin{array}{c}0 \\
0 \%\end{array}$ \\
\hline $\begin{array}{c}\text { Asian/Native American/ } \\
\text { White }\end{array}$ & $\begin{array}{c}1 \\
3.6 \%\end{array}$ & $\begin{array}{c}1 \\
3.1 \%\end{array}$ & $\begin{array}{c}0 \\
0 \%\end{array}$ & $\begin{array}{c}0 \\
0 \%\end{array}$ \\
\hline Portuguese & $\begin{array}{c}0 \\
0 \%\end{array}$ & $\begin{array}{c}1 \\
3.1 \%\end{array}$ & $\begin{array}{c}0 \\
0 \%\end{array}$ & $\begin{array}{c}0 \\
0 \%\end{array}$ \\
\hline \multirow[b]{2}{*}{ Adolescent Shared Time } & \multicolumn{2}{|c|}{$\begin{array}{l}\text { Male Adolescents } \\
\qquad(N=26)\end{array}$} & \multicolumn{2}{|c|}{$\begin{array}{l}\text { Female Adolescents } \\
\qquad(N=28)\end{array}$} \\
\hline & $\begin{array}{l}\text { Parent- } \\
\text { Shared } \\
\text { M (SD) }\end{array}$ & $\begin{array}{l}\text { Friend- } \\
\text { Shared } \\
\text { M (SD) }\end{array}$ & $\begin{array}{l}\text { Parent- } \\
\text { Shared } \\
\text { M (SD) }\end{array}$ & $\begin{array}{l}\text { Friend- } \\
\text { Shared } \\
\text { M (SD) }\end{array}$ \\
\hline Meals per day & $\begin{array}{l}1.540 \\
(0.793)\end{array}$ & $\begin{array}{c}1.430 \\
(0.790)\end{array}$ & $\begin{array}{c}1.720 \\
(1.083)\end{array}$ & $\begin{array}{c}1.480 \\
(0.769)\end{array}$ \\
\hline Weekly physical activity & $\begin{array}{c}0.680 \\
(0.983)\end{array}$ & $\begin{array}{c}4.250 \\
(2.030)\end{array}$ & $\begin{array}{c}0.930 \\
(1.388)\end{array}$ & $\begin{array}{l}3.560 \\
(2.194)\end{array}$ \\
\hline Computer hours per day & $\begin{array}{c}0.393 \\
(1.197)\end{array}$ & $\begin{array}{c}2.370 \\
(1.988)\end{array}$ & $\begin{array}{c}0.355 \\
(0.942)\end{array}$ & $\begin{array}{c}2.855 \\
(2.203)\end{array}$ \\
\hline TV hours per day & $\begin{array}{c}1.857 \\
(1.162)\end{array}$ & $\begin{array}{c}0.667 \\
(1.330)\end{array}$ & $\begin{array}{l}1.900 \\
(1.539)\end{array}$ & $\begin{array}{c}0.783 \\
(1.064)\end{array}$ \\
\hline
\end{tabular}

$\mathrm{N}=$ number of participants, $\mathrm{SD}=$ standard deviation, $\%=$ percentage of total sample, $\mathrm{TV}=$ television, $\mathrm{M}=$ sample mean.
For both genders, friend shared computer time was approximately 3 times more than parent/guardian shared; however, adolescents reported sharing about 30 more minutes of television with their parents/guardians.

Table 2 presents qualitative results from adolescent surveys. Meals shared with parents/guardians were commonly family meals, including meat, starch and fruits and vegetables. In contrast, school cafeteria food and fast/junk food was shared with friends. The majority of adolescents reported sharing no physical activity with their parents, but commonly shared exercise, sports, \&/or leisure activities with friends. Sixty-nine percent of adolescents reported a previous change to their diet, and $90 \%$ reported changing their physical activity. Reasons

Table 2. Adolescent survey questions, responses, and interpretations.

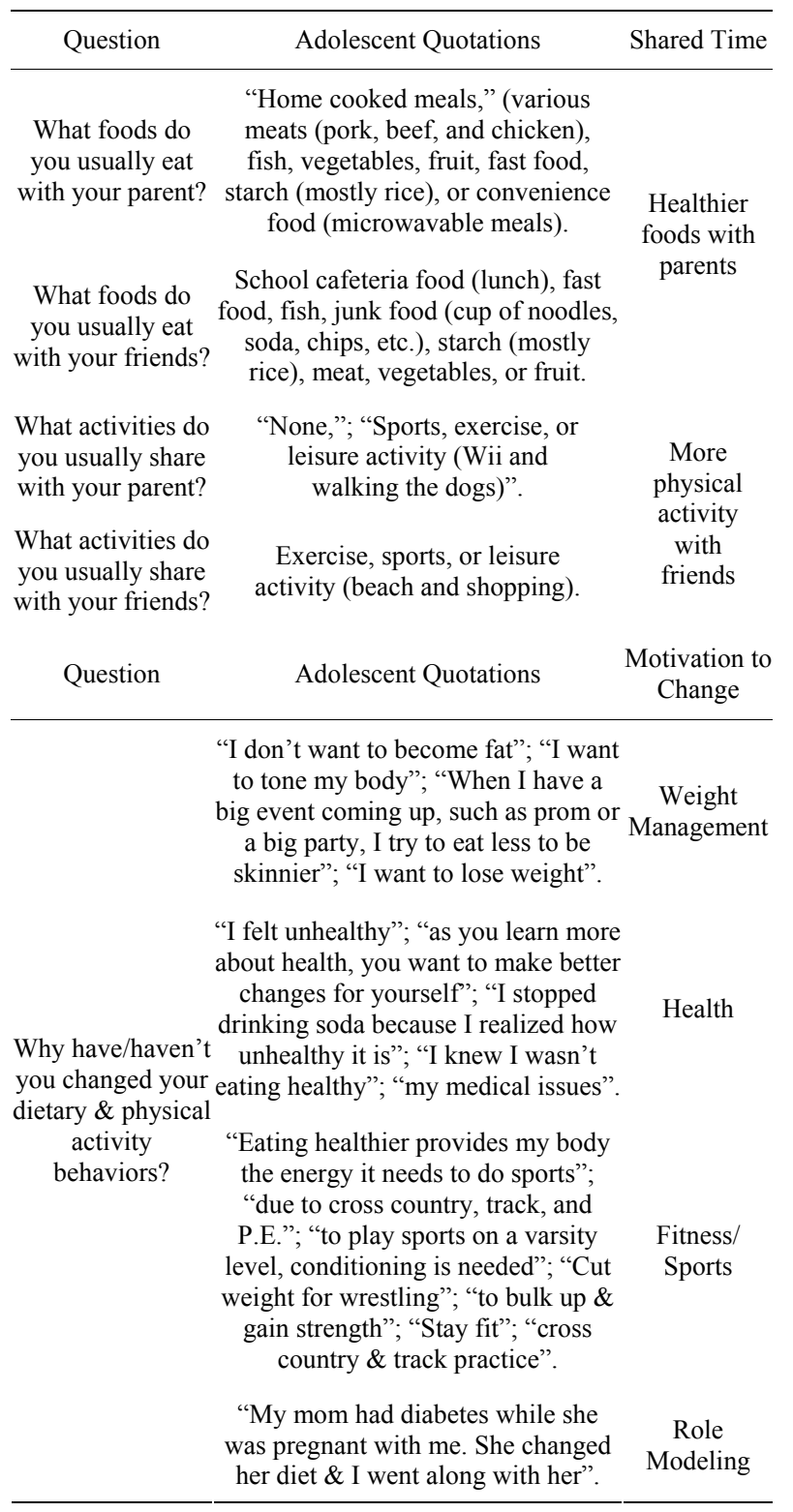


for diet and activity changes were similar across behaviors, relating to weight management, health, fitness/sport performance, and role modeling.

Table 3 shows qualitative results of adolescent-led interviews. Ninety percent of interviewed parents/guardians reported having an influence on adolescents' dietary patterns via availability/accessibility and family meals. Comparatively, the absence of family and adolescents' increasing autonomy were reported as barriers to their dietary influence. Seventy-eight percent of parents/ guardians believed they influence adolescents' physical activity, predominantly reporting instrumental social support (monetary, transportation) as enablers, and family absence and adolescent autonomy as barriers.

\section{DISCUSSION}

The present study described the parent/guardian and friend influences on Pacific Islander adolescents' dietary and activity behaviors. In general, the frequency of daily meals shared with adolescents was similar between parents/guardians and friends. However, adolescents reported considerably more physical activity with their friends, while most activities shared with parents/guardians was sedentary. The most frequently reported factors motivating adolescents' previous change to their diet and activity levels were related to weight management, health, and fitness/sport performance. Participating adolescents' focus on weight loss is noteworthy; future health-related interventions are recommended to target health and fitness related outcomes. The remaining sections review study results in comparison to previous research. Noteworthy is the absence of similar investigations among Pacific Islander adolescents. Pacific Islanders differ greatly from other groups experiencing health disparity on mainland America, likely experiencing different enablers and barriers to healthy lifestyle adoption and maintenance. Hence, current research comparisons to mainland US youth are less meaningful and should be interpreted with caution.

Comparable to mainstream research, the meals adolescents shared with their parent/guardian included healthier options and less fast/junk food than meals shared with friends. A large contributor to healthier parent/guardian shared meals is likely participants' consistent emphasis on family shared meals. This supports previous evidence demonstrating healthier dietary patterns among youth exposed to more family meals [26,31]. In contrast, adolescents reported increased fast/junk food when sharing meals with their friends; which is similar to previous associations reported between adolescent and friend group snack/soda consumption [32]. Based on current results, future intervention efforts are strongly recommended to promote healthy dietary patterns among Pacific Islander families with sensitivity to cultural foods and prefer-
Table 3. Adolescent-led parent survey questions, responses, and interpretations.

\begin{tabular}{|c|c|c|}
\hline Question & Parent Quotations & Shared Time \\
\hline $\begin{array}{l}\text { What types of } \\
\text { food do we } \\
\text { usually share? }\end{array}$ & $\begin{array}{l}\text { "Home cooked meals," (various } \\
\text { meats, fish, vegetables, fruits, } \\
\text { starches); "occasional fast food". }\end{array}$ & $\begin{array}{c}\text { Mostly } \\
\text { family meals }\end{array}$ \\
\hline $\begin{array}{l}\text { What types of } \\
\text { activities do we } \\
\text { usually share? }\end{array}$ & $\begin{array}{l}\text { "None." "television, computer"; "video } \\
\text { games"; "sports, exercise, } \\
\text { and leisure activity (washing car, } \\
\text { yard work, walking dog)". }\end{array}$ & $\begin{array}{l}\text { Commonly } \\
\text { share } \\
\text { sedentary } \\
\text { activities }\end{array}$ \\
\hline Question & Parent Quotations & $\begin{array}{c}\text { Social } \\
\text { Environment }\end{array}$ \\
\hline & $\begin{array}{l}\text { "You eat what I cook"; "I control } \\
\text { what is bought \& brought home". }\end{array}$ & Accessibility \\
\hline $\begin{array}{l}\text { Do you } \\
\text { influence } \\
\text { what I } \\
\text { eat? }\end{array}$ & $\begin{array}{l}\text { "When you're home, I make sure you } \\
\text { eat them to make sure you're eating } \\
\text { right"; "at every meal, I have you } \\
\text { guys drink milk, \& at dinner, I have } \\
\text { salad \& fruits for you"; "whatever } \\
\text { the family eats, you eat as well". }\end{array}$ & $\begin{array}{l}\text { Family } \\
\text { meals vs. } \\
\text { Autonomy }\end{array}$ \\
\hline Do you & $\begin{array}{l}\text { "By my rules"; "I provide } \\
\text { transportation \& funds; } \\
\text { "I'll sign you up". }\end{array}$ & Accessibility \\
\hline $\begin{array}{l}\text { influence my } \\
\text { physical } \\
\text { activities? }\end{array}$ & $\begin{array}{l}\text { "We hardly see each other during } \\
\text { the day"; "you're always out, I'm } \\
\text { always here"; "make your own } \\
\text { decision"; "just do it on your own". }\end{array}$ & Autonomy \\
\hline Question & Parent Quotations & $\begin{array}{c}\text { Role } \\
\text { Modeling }\end{array}$ \\
\hline $\begin{array}{l}\text { What foods do I } \\
\text { usually eat? }\end{array}$ & $\begin{array}{l}\text { "I wanted to support my mom because } \\
\text { she had diabetes while she was } \\
\text { pregnant with me. She had to change } \\
\text { her diet \& I went along with her". }\end{array}$ & $\begin{array}{l}\text { Usual foods } \\
\text { are identical }\end{array}$ \\
\hline $\begin{array}{l}\text { What physical } \\
\text { activities do you } \\
\text { participate in? }\end{array}$ & $\begin{array}{l}\text { "Sports, walking, running, weight } \\
\text { lifting \& swimming"; "none”. }\end{array}$ & \multirow{3}{*}{$\begin{array}{c}\text { Similar } \\
\text { sedentary } \\
\text { activities, } \\
\text { different } \\
\text { physical } \\
\text { activities }\end{array}$} \\
\hline $\begin{array}{l}\text { What sedentary } \\
\text { activities do you } \\
\text { participate in? }\end{array}$ & $\begin{array}{l}\text { "Television, computer activity and } \\
\text { leisure activities (reading, shopping, } \\
\text { read, conversation stories, etc.), work". }\end{array}$ & \\
\hline $\begin{array}{l}\text { What activities } \\
\text { do I participate } \\
\text { in? }\end{array}$ & $\begin{array}{l}\text { "Exercise, sports, or leisure activity } \\
\text { (beach \& shopping)". }\end{array}$ & \\
\hline
\end{tabular}

ences. School-level nutritional education is suggested to improve the healthfulness of friend-shared meals, and should be an educational priority.

Friends were revealed as a positive influence on participating adolescents' physical activity, while time shared with parents/guardians was generally sedentary. The predominant influence of friends on physical activity supports previous research among mainland US youth [27]. Also comparable to mainstream research was participants' recurring report of television as the dominant activity shared with parents/guardians [33]. One suggested strategy is promoting the substitution of shared family $\mathrm{TV} /$ movie time with activities incorporating 
physical activity (e.g., after dinner walks, sport activities, etc.). The excessive computer time shared with friends is likely a result of studying and/or social networking (e.g., Facebook, MySpace, etc.), which is a complicated barrier for health promotion efforts to overcome. One recommended approach is to facilitate after-school programs for youth, including shared time that includes physical activity (e.g., youth sport, outdoor activities, etc.), rather than sedentary behaviors.

Along with the influence of shared time on adolescents' health behaviors, participants emphasized the significance of availability/accessibility and adolescent autonomy. A larger proportion of participating parents/ guardians believed they influence their adolescents diet (90\%) compared to their physical activity (78\%). Relative to influencing physical activity, participating parents/guardians perceived adolescent autonomy as a common barrier ("you're always out, I'm always here"). And, On the other hand, most parents reported a strong influence on adolescents' dietary behaviors. Results suggest participating adolescents remain highly vulnerable to foods within the home environment, with parents managing most food opportunities and options ("I control what is bought and brought home"); which reflects evidence among mainland US youth [34]. Therefore, similar to other American youth (majority White European American), the direct promotion of Pacific Islander adolescents' healthy diet is likely a pointless endeavor without consideration for the authoritative entities ruling the surrounding food environment. One approach is adolescent empowerment, and the strategic use of youth as the vehicles driving intervention efforts into the home environment. For example, research has examined empowerment strategies targeting youth confidence to request healthier food options and physical activity opportunities from their parents (i.e., proxy efficacy) [35,36]. Future investigations should build on these findings by evaluating similar efforts among Pacific Islander youth populations.

\section{CONCLUSION}

Certain study limitations/strengths were noteworthy. First, the sample was relatively small and specific to Pacific Islander youth attending a private school, limiting generalizability of study outcomes to other populations and school contexts. Additionally, outcomes were based on adolescent and parent self-report, introducing the risk for social desirability bias. The current research was also limited to factors within adolescents' social environment, requiring similar examinations to determine the most salient influences within the surrounding physical environment. One main advantage was the unique youth-led research approach; not only did parent interviews serve as a potential catalyst for future health conversations, adolescents' participation facilitated a gateway to the home environment.

One goal of Healthy People 2010 was to eliminate health disparities [37]; however, evidence-based, culturally adapted interventions remained severely warranted. The current research is among the first investigations of Pacific Islander adolescents' multiple health behavior. Our intention was to provide a preliminary understanding of the social environmental influences impacting the health behaviors of a highly understudied and at-risk youth population. There is growing interest in developing effective theory-based approaches to weight control in minority populations [38], and multiple health behavior promotion is likely the best practice approach [30]. In absence of similar investigations, current outcomes provide groundwork in the development of culturally appropriate multiple health behavior interventions targeting similar Pacific Islander populations.

\section{ACKNOWLEDGEMENTS}

This study is funded by the National Cancer Institute R25 CA90956 \& CURE Supplement P30 CA071789.

\section{REFERENCES}

[1] Ogden, C.L., Carroll, M.D., Curtin, L.R., Lamb, M.M. and Flegal, K.M. (2010) Prevalence of high body mass index in US children and adolescents, 2007-2008. JAMA, 303, 242-249. http://dx.doi.org/10.1001/jama.2009.2012

[2] Guo, S.S., Roche, A.F., Chumlea, W.C., Gardner, J.D. and Siervogel, R.M. (1994) The predictive value of childhood body mass index values for overweight at age 35. American Journal of Clinical Nutrition, 59, 810-819.

[3] Daniels, S.R. (2006) The consequences of childhood overweight and obesity. Future Child, 16, 47-67. http://dx.doi.org/10.1353/foc.2006.0004

[4] Must, A., Jacques, P.F., Dallal, G.E., Bajema, D.J. and Dietz, W.H. (1992) Long-term morbidity and mortality of overweight adolescents: A follow-up of the Harvard Growth study of 1922 to 1935. New England Journal of Medicine, 327, 1350-1355.

http://dx.doi.org/10.1056/NEJM199211053271904

[5] Schwimmer, J.B., Burwinkle, T.M. and Varni, J.W. (2003) Health-related quality of life of severely obese children and adolescents. JAMA, 289, 1813-1819.

http://dx.doi.org/10.1001/jama.289.14.1813

[6] Wang, G. and Dietz, W.H. (2002) Economic burden of obesity in youths aged 6-17 years: 1979-1999. Pediarics, 109, e81-e81.

http://www.pediatricsdigest.mobi/content/109/5/e81.full

[7] Baruffi, G., Hardy, C.J., Waslien, C.I., Uyehara, S.J. and Krupitsky, D. (2004) Ethnic differences in the prevalence of overweight among young children in Hawaii. Journal of the American Dietetic Association, 104, 1701-1707. http://dx.doi.org/10.1016/i.jada.2004.08.027

[8] Davis, J., Busch, J., Hammatt, Z., Novotny, R., Harrigan, 
R., Grandinetti, A. and Easa, D. (2004) The relationship between ethnicity and obesity in Asian and Pacific Islander populations: A literature review. Ethnicity \& Disease, 14, 111-118.

[9] Grandinetti, A., Chang, H.K., Theriault, A. and Mor, J. (2005) Metabolic syndrome in a multiethnic population in rural Hawaii. Ethnicity \& Disease, 15, 233-237.

[10] Janssen, I., Katzmarzyk, P.T., Boyce, W.F., Vereecken, C., Mulvihill, C., Roberts, C., Curie, C. and Pickett, W. (2005) Comparison of overweight and obesity prevalence in school-aged youth from 34 countries and their relationships with physical activity and dietary patterns. Obesity Reviews, 6, 123-132.

http://dx.doi.org/10.1111/j.1467-789X.2005.00176.x

[11] Sisson, S.B., Broyles, S.T., Baker. B.L. and Katzmarzyk, P.T. (2011) Television, reading, and computer time: Correlates of school-day leisure-time sedentary behavior and relationship with overweight in children in the US. Journal of Physical Activity and Health, 8, S188-S197.

[12] Nicklas, T.A., Yang, S.J., Baranowski, T., Zakeri, I. and Berenson, G. (2003) Eating patterns and obesity in children: The Bogalusa Heart Study. American Journal of Preventive Medicine, 25, 9-16. http://dx.doi.org/10.1016/S0749-3797(03)00098-9

[13] Troiano, R.P., Berrigan, D., Dodd, K.W., Masse, L.C., Tilert, T. and McDowell, M. (2008) Physical activity in the United States measured by accelerometer. Medicine and Science in Sports and Exercise, 40, 181-188. http://dx.doi.org/10.1249/mss.0b013e31815a51b3

[14] Mavoa H.M. and McCabe, M. (2008) Sociocultural factors relating to Tongans' and Indigenous Fijians' patterns of eating, physical activity and body size. Asia Pacific Journal of Clinical Nutrition, 17, 375-384.

[15] Moy, K.L., Sallis, J.F. and David, K.J. (2010) Health indicators of Native Hawaiian and Pacific Islanders in the United States, Journal of Community Health, 35, 81-92. http://dx.doi.org/10.1007/s10900-009-9194-0

[16] American Academy of Pediatrics, Committee on Public Education, American Academy of Pediatrics (2001) Children, adolescents, and television. Pediatrics, 107, 423426. http://dx.doi.org/10.1542/peds.107.2.423

[17] Eaton, D.K., Kann, L., Kinchen, S., Shanklin, S., Flint, K.H., Hawkins, J. and Lim, C. (2012). Youth risk behavior surveillance-United States, 2011. MMWR Surveillance Summaries, 61, 1-162.

[18] Boynton-Jarrett, R., Thomas, T.N., Peterson, K.E., Wiecha, J., Sobol, A.M. and Gortmaker, S.L. (2003) Impact of television viewing patterns on fruit and vegetable consumption among adolescents. Pediatrics, 112, 1321-1326. http://dx.doi.org/10.1542/peds.112.6.1321

[19] Campbell, K.J., Crawford, D.A., Salmon, J., Carver, A., Garnett, S.P. and Baur, L.A. (2007) Associations between the home food environment and obesity-promoting eating behaviors in adolescence. Obesity, 15, 719-730. http://dx.doi.org/10.1038/oby.2007.553

[20] Johnson, D.B., Birkett, D., Evens, C. and Pickering, S. (2005) Statewide intervention to reduce television viewing in WIC clients and staff. American Journal of Health Promotion, 19, 418-421. http://dx.doi.org/10.4278/0890-1171-19.6.418

[21] Stokols, D. (1996) Translating social ecological theory into guidelines for community health promotion. American Journal of Public Health, 10, 282-298.

[22] Golan, M. and Crow, S. (2004) Parents are key players in the prevention and treatment of weight-related problems. Nutrition Reviews, 62, 39-50. http://dx.doi.org/10.1111/j.1753-4887.2004.tb00005.x

[23] Golan, M. (2006) Parents as agents of change in childhood obesity-From research to practice. International Journal of Pediatric Obesity, 1, 66-76. http://dx.doi.org/10.1080/17477160600644272

[24] Lindsay, A.C., Sussner, K.M., Kim, J. and Gortmaker, S.L. (2006) The role of parents in preventing childhood obesity. Future Child, 16, 169-186. http://dx.doi.org/10.1353/foc.2006.0006

[25] Finnerty, T., Reeves, S., Dabinett, J., Jeanes, Y.M. and Vogele, C. (2009) Effects of peer influence on dietary intake and physical activity in schoolchildren. Public Health Nutrition, 13, 376-383. http://dx.doi.org/10.1017/S1368980009991315

[26] Geller, K.S. and Dzewaltowski, D.A. (2009) Longitudinal and cross-sectional influences on youth fruit and vegetable consumption. Nutrition Reviews, 67, 65-76. http://dx.doi.org/10.1111/j.1753-4887.2008.00142.x

[27] Wigfield, A. and Wagner, A.L. (2005) Competence, motivation, and identity development during adolescence. Handbook of Competence and Motivation, 222-239.

[28] Springer, A.E., Kelder, S.H. and Hoelscher, D.M. (2006) Social support, physical activity and sedentary behavior among 6th-grade girls: A cross-sectional study. International Journal of Behavioral Nutrition and Physical Activity, 3, 8. http://dx.doi.org/10.1186/1479-5868-3-8

[29] Yasui, M. and Dishion, T.J. (2007) The ethnic context of child and adolescent problem behavior: Implications for child and family interventions. Clinical Child and Family Psychology Review, 10, 137-179. http://dx.doi.org/10.1007/s10567-007-0021-9

[30] Wilson, D.K. and Kitzman-Ulrich, H. (2008) Cultural considerations in the development of pediatric weight management programs. In: Jelalian E. and Steele R.G., Eds., Handbook of Child and adolescent Obesity, Springer, New York, 293-310.

[31] Haapalahti, M., Mykkanen, H., Tikkanen, S. and Kokkonen, J. (2003) Meal patterns and food use in 10- to 11year-old Finnish children. Public Health Nutrition, 6, 365-370. http://dx.doi.org/10.1079/PHN2002433

[32] Wouters, E.J., Larsen, J.K., Kremers, S.P., Dagnelie, P.C. and Geenen, R. (2010) Peer influence on snacking behavior in adolescence. Appetite, 55, 11-17. http://dx.doi.org/10.1016/j.appet.2010.03.002

[33] He, M., Piché, L., Beynon, C. and Harris, S. (2010) Screenrelated sedentary behaviors: Children's and parents' attitudes, motivations, and practices. Journal of Nutrition Education and Behavior, 42, 17-25. http://dx.doi.org/10.1016/j.jneb.2008.11.011

[34] Bere, E. and Klepp, K.I. (2005) Changes in accessibility and preferences predict children's future fruit and vegeta- 
ble intake. International Journal of Behavioral Nutrition and Physical Activity, 2, 15.

http://www.ijbnpa.org/content/2/1/15

[35] Dzewaltowski, D.A., Geller, K.S., Rosenkranz, R.R. and Konstantinos, K. (2010) Children's self-efficacy and proxy efficacy for after-school physical activity. Psychology of Sport \& Exercise, 11, 100-106.

http://dx.doi.org/10.1016/j.psychsport.2009.08.001

[36] Geller, K.S. and Dzewaltowski, D.A. (2010) Youth proxy efficacy for fruit and vegetable availability varies by gender and socioeconomic status. Public Health Nutrition, 13,
843-851. http://dx.doi.org/10.1017/S1368980009993223

[37] United States Department of Health and Human Services (USDHHS) (2010) Healthy People 2010 (Conference Edition, in Two Volumes). US Government Printing Office, Washington DC.

[38] Ye J., Rust, G., Baltrus, P. and Daniels, E. (2009) Cardiovascular risk factors among Asian Americans: Results from a National Health Survey. Annals of Epidemiology, 19, 718-723.

http://dx.doi.org/10.1016/j.annepidem.2009.03.022 